\title{
Cognitive Science Could Be Used in Legal Reasoning - Take Smith v. Van Gorkom Case as an Example
}

\author{
Rongrong Zhou \\ Shandong High People's Court, Ji'nan, China \\ Email: rongrong8799@126.com
}

How to cite this paper: Zhoum, R. R. (2016). Cognitive Science Could Be Used in Legal Reasoning-Take Smith v. Van Gorkom Case as an Example. Psychology, 7, 1719-1726.

http://dx.doi.org/10.4236/psych.2016.713161

Received: October 17, 2016

Accepted: November 15, 2016

Published: November 18, 2016

Copyright $\odot 2016$ by author and Scientific Research Publishing Inc. This work is licensed under the Creative Commons Attribution International License (CC BY 4.0).

http://creativecommons.org/licenses/by/4.0/

\begin{abstract}
The newer research finds that our conceptualization and reasoning are grounded in our bodily experience and shaped primarily by patterns of perception and action. We use metaphor to understand the conceptions. Conceptual structures form the basic understanding of the scenario. Holfeldian analysis provides an interpretation of the categories of different entities. The framing and schema drives people's minds into divergent directions. Smith v. Van Gorkom case is used to interpret the cognitive process.
\end{abstract}

\section{Keywords}

Reasoning, Metaphor, Holfeldian Analysis, Framing

\section{Introduction}

Instead of seeing the mind as a disembodied computer program, the newer research reveals that our conceptualization and reasoning are grounded in our bodily experience and shaped primarily by patterns of perception and action (Lakoff \& Johnson, 1999). This new cognitive science of the embodied mind is predicated on the assumption that there is no human conceptualization or reasoning without a functioning human brain, which operates a living human body that is continually engaging environments that are at once physical, social, cultural, economic, moral, legal, gendered, and racialized (Johnson, 2011). Reasoning is the activation of certain neuronal groups in the brain given prior activation of other neuronal groups (Lakoff, 2008). Using cognitive science to reason legal cases will help us better understand the mechanism.

Taking Smith v. Van Gorkom case as an example, Smith v. Van Gorkom (488 A.2d 
858 (Del. Sup. Ct. 1985)) is a significant case in American corporate law (Klein, Ramseyer, \& Bainbridge, 2009). Plaintiffs, shareholders of Trans Union, sued seeking rescission of a merger into the new company, or, alternatively, damages against Trans Union's board. Trans Union was profitable but wasn't able to use all its tax credits. Van Gorkom, on his own approached a takeover specialist who eventually came up with a price above the market value, but no study was done to determine the intrinsic value. Although board members knew the company well, that was not enough to base a finding that they had reached an informed decision, and thus the court held the directors of Trans Union breached their fiduciary duty to their stockholders.

\section{Case Brief}

Trans Union is a leasing company dealing with mainly railroad cars. Their business generated lots of investment tax credits (ITC) due to favorable tax treatment for purchase railroad cars. Credits were about to expire unused because Trans Union had insufficient taxable income. It had lots of extra cash but no investment opportunities, and is a natural candidate for acquisition.

Trans Union chairman Van Gorkom decided to sell company through an leveraged buyout, and negotiated the issue with financier Jay Pritzker. According to Delaware law, the merger must be approved by the boards of directors and shareholders of both acquiring and target corporations.

In 1980 Aug. to Sept., there was an internal management discussion. The stock was at $\$ 38$, and CFO Romans runs financing feasibility study, indicating that easy at $\$ 50$ but hard at $\$ 60$. Van Gorkom said that he would take \$55. In 1980 Sept. 13-19, Van Gorkom negotiated leveraged buyout at $\$ 55$ per share with Pritzker. In 1980 Sept. 20 morning, a senior management meeting was held, and in the afternoon the Trans Union Board of Directors approved the merger agreement. In 1981 Feb. 10, Trans Union shareholders approved the merger, and the vote was $69.9 \%$ to $7.25 \%$ (22.85 abstained).

The issue is: did the directors violate the duty of care in approving the merger? In analyzing this issue, the Business Judgment Rule (BJR) should be considered. BJR means a presumption that in making a business decision, the directors of a corporation should act on an informed basis, in good faith, and in the honest belief that the action taken was in the best interests of the company. There were several exceptions, which were fraud, illegal conduct, self-dealing and egregious misconduct, which should not be protected by the BJR.

Duty of Care in context of the proposed merger means the duty "to act in an informed and deliberate manner in determining whether to approve an agreement of merger before submitting the proposal to the stockholders" (Allen et al., 2012). "A director may not abdicate that duty by leaving to the shareholders alone the decision to approve or disapprove the agreement." In Van Gorkom case, the BJR affords no protection for uniformed decision, and the plaintiff must prove that board of directors failed to inform itself of "all material information reasonably available to them", and also a gross negligence by directors. The board knew Pritzker was willing to pay a $\$ 17$ pre- 
mium over the prevailing market price. This was not enough, because the board doesn't know how Van Gorkom set the price, price based on study of intrinsic value rather than financing feasibility, and what control is actually worth to Pritzker.

There was a limitation of the market price as a measure of true value. "A publiclytraded stock price is solely a measure of the value of a minority position and, thus, market price $\$ 38$ represents only the value of a single share." Market price is thus improper measure of adequacy of the offered price (\$55). Stock consists of two rights, which is economic and voting. As an owner, shareholders are entitled to their shares of the profits and can vote on important decisions and ruling. A single share of stock gives the owner little control over the company, and the market price of a share of stock thus may reflect nothing more than the estimated present value of the future stream of dividends payable on that share. Someone buying a controlling block of stock potentially gets the ability to elect the entire board of directors, hence he can change the corporate management and policies to make firm more valuable.

There is no apparent effort to determine how much control would be worth to Pritzker. Because of the absent of a determination, there was no basis for deciding whether the price was a fair one. Trans Union's own estimate suggested that a price of up to $\$ 60$ per share would be feasible. Even though there was only a 5 dollar per share difference, in total it would be about 63 million dollars.

The DGCL 141(e) did not protect the directors' reliance on Van Gorkom, even though it provided a defense for directors who rely in good faith on reports from officers, not blindly. Because there was no evidence that any report was presented to the board, but only uninformed oral statements.

The board illustrated a "market test" defense, meaning a 90-day test period would put company up for auction and validate $\$ 55$ price as fair. This defense did not work because the terms of the agreement did not permit a fair market test, Trans Union could not solicit bids nor provide proprietary information to bidders. Pritzker's lock-up option may have been a deal killer.

The court finally held that "the directors of Trans Union breached their fiduciary duty to their stockholders, and the Court of Chancery shall conduct an evidentiary hearing to determine the fair value of the shares represented by the plaintiff's class, based on the intrinsic value of Trans Union on September 20, 1980... Thereafter, an award of damages should be entered to the extent that the fair value of Trans Union exceeded \$55 per share."

\section{Metaphor Analysis}

Several core elements are important to discuss by metaphor analysis.

\subsection{Leveraged Buyout}

The first one is leverage buyout. Leveraged buyout is to use a large amount of debt to acquire a company, and the debt is paid off over time, often through sale of assets (Pignataro, 2013). This is like a flow of water, the debt used to acquire the company is like a 
large amount of water, and the company is like a container. The pay off process is like a flow back of the water, the water is not poured once a time; but over time, like a stream. The sale of assets is like the water drop, collected into the stream and formed a flow circle.

\subsection{Business Judgment Rule}

The other concept is Business Judgment Rule. Business Judgment Rule is a presumption that in making business decision, the directors of a corporation acted on an informed basis, in good faith, and in honest belief that the action taken was in the best interests of the company (Radin, 2013). This is like a standard, a line, which the directors should try their best to achieve. The line is up in the air, including merits of fully disclosure, good faith, and honest belief. This objective line is set as the reference to determine whether the director is acting appropriately, in order to decide whether the director should be protected.

\subsection{Market Value, Intrinsic Value}

The other two significant terms are market value and intrinsic value. Market value is changed with the stock circumstance, is the price at which an asset would trade in a competitive auction setting. However, intrinsic value refers to the value of a security which is intrinsic to or contained in the security itself. It is also frequently called fundamental value. If the company is like a box, the market is like an auction, then the market value is the auction price of the box, which is determined by the outside buyers. Intrinsic value is the book value of the box itself. In Van Gorkom case, the price in the merger is not tested and decided carefully taking both market value and intrinsic value into consideration, that is one of the reasons that the directors violate their fiduciary duty.

\section{4. "Informed"}

Information is like the code inside a company, the process to disclose it is like a translation of the code into normal language and let others know what it means. The more appropriate metaphor is that information is like a bread in a person's house, disclosure means the process to share the bread with others. During the disclosure, directors will be exposed to the code, the bread, and understand, taste it, then form their own understanding. Only upon this can they be relieved from fiduciary duty obligation.

\subsection{Duty of Care}

Duty of Care, which is a significant concept in corporate law, can also be analyzed by metaphor. Duty of care means that each member of the board of directors, when discharging the duties of a director, shall act in good faith, and in a manner the director reasonably believes to be in the best interest of the corporation. If the company is like a car, the directors are drivers, then the standard of care is like a safeguard, which is required during the driving process. It is the obligation and also a protection for safe 
driving. Directors who do not pay such care to the operation of the car should be liable.

\subsection{Market Test}

Market test is like a balance on a scale, one side is the company, and the other side is the outside competitors. This balance should be kept within 90 days, and the defendant held it as an excuse of fiduciary duty. However, in understanding the valuation, the non-compete term is not the key issue. The directors did not provide proprietary information to bidders, and Pritzker's lock-up option may have been a deal killer. These factors interfered the fair market test and precluded the directors from business judgment rule.

\section{Hohfeldian Analysis}

According to Hohfeld's theory, legal conceptions have practical value, and anima mundi, constituent elements (Hohfeld, 2011). Hereditament has two categories, one is corporeal, which is figurative and fictional, the other is incorporeal, which exist only in contemplation. And he used eight elements to illustrate the legal concept, which is showed in Table 1.

In Van Gorkom case, the major entities are Van Gorkom, Pritzker, other directors and the shareholders. Van Gorkom has a right to negotiate a sale of the company with the outside financier, which means the other directors has a duty not to interfere the negotiation. Van Gorkom has the liability to inform the information and price valuation to the board of directors, means the other directors have the power to get information in order to make wise decision. If Van Gorkom is disabled to inform the other directors, he has the immunity to the punishment of the fiduciary duty obligation, but if he is able but did not do so, he has the liability. Directors except Van Gorkom has the right to get the adequate information, and has the liability to act in good faith, reasonably belief, and for the best interests of the company. If other directors' decision fits the standard, then they have the immunity of fiduciary duty obligation. In Van Gorkom case, other directors did not determine how much control would be worth to Pritzker, because of the lack of information, and negligence of the intrinsic value of the price, thus there was no basis for deciding whether the price was a fair one.

This leads to the conclusion that the directors did not act in duty of care and violate the obligation to shareholders. However, in the dissenting opinion, the judge held that the directors are independent and experienced businessmen, who has the discretion to

Table 1. Basic legal concepts.

\begin{tabular}{ccc}
\hline Elements & Correlatives & Opposites \\
\hline Right & Duty & No right \\
Privilege or liberty & No right & Duty \\
Power & Liability & Disability \\
Immunity & Disability & Liability \\
\hline
\end{tabular}


decide business issues based on their empirical standard. They have the power and no liability to the business decision, thus no violation of duty to the shareholders. By using the Hohfeldian analysis, each entity's rule and action finds a reasonable interpretation. They are set in a schema and this will facilitate the logic in framing analysis.

\section{Framing Analysis}

The Horsey Justice (for the majority) held the opinion that the board of directors should be liable for the gross negligence in deciding the merger. However, the dissenting opinion held that the directors are experienced and are not ordinarily taken in by a "fast shuffle". They knew the company "like the back of their hands", and "at the time an integral part of that world", meaning that they have made the professional decision even not intellectual figureheads.

The different position represents different frames and caused different results. The Horsey Justice's opinion inclines to burden the directors and is in favor of the shareholders. In this scenario, the directors are agent of the shareholders. Their decisions are under strict scrutiny. This triggers the interest conflict between directors and shareholders. In this schema, the shareholders are at a higher level of the stage, like the screenwriter of a drama. The company is like a stage, and the directors are like actors and actresses who are selected by the screenwriter. They are set in this situation. Their actions have produced a change, which may be not in the best will of the screenwriter. They have to decide the merger issue with best knowledge and adequate information.

Frame analysis as rhetorical criticism that "induce us to filter our perceptions of the world in particular ways, essentially making some aspects of our multi-dimensional reality more noticeable than other aspects. They operate by making some information more salient than other information... Frames operate in four key ways: they define problems, diagnose causes, make moral judgments, and suggest remedies" (Petruck, 1996).

The definition of director is different from the concurring perspective and the dissenting perspective. The concurring part treat the directors as the nominees and servants of the shareholders. However, the dissenting part treat them as independent and experienced, sophisticated business people.

The diagnose causes are also different. The concurring opinion treat this information disclosure process informal and not complete. The lack of outside resources and inspection caused the gross negligence of the director. However, the dissenting opinion held the decision was fair but unwise, by not intellectual figureheads. This is the individual's weakness.

The moral judgments are also different. Judge Horsey probably relied on utilitarianism theory, which is inclined to protect the majority's interest. However, the dissenting Justice, McNeilly, perhaps relied on Kantianism, which respects the individual's moral categorical imperative. Different moral standards lead to different policy tendentiousness.

Because of the different frames, the suggest remedies are different. In the former 
frame, the remedy is to burden the directors to pay damages for their "gross negligence". Directors are blamed because of the lack of information. The information collection system is based on the external disclosure. The disclosure mechanism is based on the majority interest consideration. This chain forms the logical frame to damage the directors.

On the contrary, the dissenting opinion held that directors are protected by their business sensitivity. Their decision is protected by the business judgment rule, and not in bad faith, not in conflict of the company. It is more favorable to the freedom of directors, and is incentive for the directors. This frame focuses on a person's internal reasonableness and integrity, trust and fidelity. Meanwhile, this is a more individualized anatomy and remedy recommendation, in contrast with the empiricism based blame.

\section{Conclusion}

According to George Lakoff's theory, the differences in opinions between the concurring justice and dissenting justice may follow from the fact that they subscribe with different strength to two different metaphors about the relationship of the directors to their shareholders. "We are neural beings," Lakoff states. "Our brains take their input from the rest of our bodies. What our bodies are like and how they function in the world thus structures the very concepts we can use to think. We cannot think just anything-only what our embodied brains permit" (Blommaert, 1996). This helps us better understand Van Gorkom case.

Conceptual structures form the basic understanding of the scenario. Holfeldian analysis provides an interpretation of the categories of different entities. These fall into the framing analysis, which is the key feature of the cognitive science and legal reasoning. The framing and schema drives the judges' mind into divergent directions, categorized as public and individual. It is like driving a car to distinct destinations. Because of the different analytic structure, even they carry the same ideal of equity and fairness, their reasoning and decisions are diversified.

\section{References}

Allen, W. T. et al. (2012). Commentaries and Cases on the Law of Business Organization (4th ed.). Wolters Kluwer Law \& Business.

Hohfeld, W. N. (2011). Some Fundamental Legal Conceptions as Applied in Judicial Reasoning. Yale Law Journal, 23, 1913-1914.

Johnson, M. L. (2011). Mind, Metaphor, Law. Mercer Law Review, 58.

Klein, W. A., Ramseyer, J. M., \& Bainbridge, S. M. (2009). Business Associations-Cases and Materials on Agency, Partnerships, and Corporation (7th ed.). Foundation Press.

Lakoff, G. (2008). The Neural Theory of Metaphor. In R. Gibbs (Ed.), The Metaphor Handbook. Cambridge University Press. http://dx.doi.org/10.1017/cbo9780511816802.003

Lakoff, G., \& Johnson, M. (1999). Philosophy in the Flesh: The Embodied Mind and Its Challenge to Western Thought. Basic Books.

Petruck, M. R. L. (1996). Frame Semantics. In J. Verschueren, J.-O. Östman, J. Blommaert, \& C. 
Bulcaen (Eds.), Handbook of Pragmatics. John Benjamins.

Pignataro, P. (2013). Leveraged Buyouts, + Website: A Practical Guide to Investment Banking and Private Equity. Wiley.

Radin, S. A. (2013). Business Judgment Rule: Fiduciary Duties of Corporate Directors (6th ed.). Wolters Kluwer Law \& Business.

Submit or recommend next manuscript to SCIRP and we will provide best service for you:

Accepting pre-submission inquiries through Email, Facebook, LinkedIn, Twitter, etc. A wide selection of journals (inclusive of 9 subjects, more than 200 journals)

Providing 24-hour high-quality service

User-friendly online submission system

Fair and swift peer-review system

Efficient typesetting and proofreading procedure

Display of the result of downloads and visits, as well as the number of cited articles Maximum dissemination of your research work

Submit your manuscript at: http://papersubmission.scirp.org/

Or contact psych@scirp.org 